\title{
Exposure of Mathematics Education Students to the Usage of Technology in their Training Programme in Ghana
}

\author{
Emmanuel Agyei *, Bernard Wiafe Akaadom **, Bright Kwaku Manu**** \\ * Department of Mathematics and ICT Education, University of Cape Coast \\ ** Department of Mathematics and ICT Education, University of Cape Coast \\ *** Department of Mathematics, Ghana Christian International School
}

DOI: 10.29322/IJSRP.10.05.2020.p10158

http://dx.doi.org/10.29322/IJSRP.10.05.2020.p10158

\begin{abstract}
The emergence of technology has impacted several disciplines of human life. The overall objective of the study was to explore the extent to which Bachelor of Education (Mathematics) students of the University of Cape Coast (UCC) are exposed to the utilization of technology tools in their programme of study. A descriptive survey design was adopted for the study. The population considered was all Bachelor of Education (Mathematics) students at the University of Cape Coast. A total of 120 students were carefully selected for the study using purposive sampling. The main instrument used in collecting data was a questionnaire. The key findings of the study established that, although mathematics education students have a positive perception of the usage of technology, the students have very little exposure to technology in their learning programme. With reference to the finding, it was suggested that the institution should inculcate technology in mathematics education by making ICT a minor course for the Bachelor of Education (Mathematics) programme.
\end{abstract}

Index Terms- Technology, Mathematics Education, perception, ICT

\section{INTRODUCTION}

$\mathrm{T}$ he society incorporates a rotary co-dependence on technology; technology and human life cannot be separated. Humans use technology; depend on technology diversely in our daily lives, and our desires and demands for technology continue to rise. Technology helps individuals to communicate, learn, do business and live in comfort (Karehka, 2012). Currently, with the changes in the curriculum and the rise in the usage of technology, it is expedient to look at the issue of inculcating technology in mathematics education to prepare student teachers for the future. Karehka (2012) discovered that education has been made remote due to the inception of technology. He further indicated that, with the introduction of internet technology, the education sector has experienced a new form of education known as online education. $\mathrm{He}$ also reiterated that, presently, students are mostly capable of studying courses that are provided in other near and distant countries without encountering any adverse limitations. Thus, technology has led to the globalization of education. Strauss (2017) also revealed in a study that the majority of Americans mention technology more than any other form of advancement when they are asked about what is responsible for the largest enhancement in their lives for the previous five (5) decades. However, Africa which is the second-largest continent appears to be the "missing continent" in terms of information technologies (Odedra, Lawrie, Bennett \& Goodman, 2008). Odedra et al. (2008) further indicated that Africa is the least computerized, and more than its two-score countries have an average telephone density that is smaller than that of the European community in order of magnitude. Furthermore, Intsiful, Okyere, and Osae, (2003) have indicated that ICT in Ghana is still in its early stages although the country was the first to access internet connectivity in sub-Sahara Africa. University education is regarded as a key factor for economic sustainability; hence it is very necessary to train university students in a way that will empower them with skills and expertise that would be relevant for their success in this present information world (Addy \& Ofori-Boateng, 2015). A study to identify the extent to which mathematics education students are exposed to the utilization of technological tools will provide rich insight into why there is a need to integrate technology in mathematics education.

Technology has been defined by several scholars as the application of the knowledge and utilization of tools (machines) and skills to control one's surroundings. According to Lowerison, Sclater, Schmidt, and Abrami (2012), technology can change the learning environment from passive(inactive) to active. Thus, technology has the potential to subject a lesson to the control of the student. Roblyer (2013) also states that the usage of technology may empower the learner to be more vigorously involved the mathematics instruction. Similarly, Pramela and Noraza (2007) reported that the utilization of technological tools and equipment assisted in attracting the students' attention and maintaining their interest so that they were able to gain and master relevant skills. They also stated that the use of ICT has facilitated and enhanced the teaching of mathematics. Lisa (2005) also emphasized that media materials can be used as teaching aids to help resolve the delivery of more abstract concepts. Thus, this study also conforms to the findings of Krishnasamy, Veloo, and Hooi (2013) who reported that the perceptions of mathematics teachers suggest that schools require ICT facilities to enhance mathematics instruction. 
In Ghana, it cannot be overemphasized how technology has influenced both social and economic transformation. In the educational sector, the traditional way of teaching is the method that is always adopted instead of a more modern way of teaching where a bit of technology is inculcated since there are no Information Technology (IT) tools available in this field to assist in Technological Pedagogical Content Knowledge (TPCK) amongst students. Information Technology (IT) is also generally believed to provide many application software that makes the learning of mathematics easier than complex, faster than slower and more meaningful than abstract. Examples of this application software include Spreadsheet, Geogebra, Matlab, LaTeX, Octave, etc. As technology is affecting almost every aspect of human life, it is important that we change the way mathematics is being taught in schools. With the evolution of new concepts, teachers are expected to enhance learning and make it more meaningful to students rather than providing only knowledge. This can be done by exposing students to these technological tools so that they can integrate technology in the learning of mathematics. It is for this reason that the researchers sought to explore the extent to which the B. Ed. Mathematics program offered at the University of Cape Coast (UCC) trains students to integrate and apply technology in the teaching of mathematics.

\section{Research Questions}

The study sought to find answers to these questions:

1. What are the perceptions of B. Ed. Mathematics students about the inculcation of technology in mathematics education?

2. What technological tools are mathematics education students of UCC exposed to in their program?

3. To what extent are B. Ed. Mathematics students of UCC exposed to the utilization of technological tools in their program?

\section{LITERATURE REVIEW}

\subsection{TPACK Theoretical Framework}

The TPACK framework was adopted as the major theoretical framework underpinning the study. Mishra and Koehler (2006) introduced Technological Pedagogical Content Knowledge (TPCK) as a conceptual basis to appreciate the prerequisite knowledge and expertise that is relevant to teachers to effectively inculcate technology in the teaching and learning process. The term TPCK was coined from the concept "pedagogical content knowledge" (PCK) (Shulman, 1986 as cited by Agyei, 2012) which pinpoints the relevance of the multifaceted interrelationships between teachers' knowledge about content and pedagogy. According to Voogt et al. (2012) PCK is regarded as an exceptional element that characterizes the teacher's occupation. Thus, teachers can fit in domain knowledge with the relevant pedagogical methods to enable the learner to comprehend and appreciate the subject under discussion. Voogt et al. (2012) further expounded two relevant features of what is familiar in PCK. First, PCK describes the illustrations of domain knowledge and second, comprehension of peculiar challenges of learning and conceptions of students linked to the instruction of certain subjects of the domain. A comprehensive form of PCK is known to be T(PCK). This concept is fast evolving and shares similar views as PCK. Voogt et al. (2012) asserted that TPCK embraces technology knowledge (TK) which is regarded as a very essential component in the teacher's occupation. Thompson and Mishra (2007) indicated that TPCK was transformed into TPACK in the year 2007 which denotes Technology, Pedagogy, and Content Knowledge. Thus, teaching effectively with technology. Several studies (Cox \& Graham 2009; Neiss 2011; Agyei, 2012) have revealed that incorporating ICT in teaching and learning is a rare practice and this phenomenon is not a well-recognized practice in most pre-service teachers' preparation programmes and teacher education programmes within the mathematics education setting. Furthermore, TPACK may provide an appropriate and better understanding of the possible contributions of the evolving technologies. Again, TPACK has the potential to assist various learners in the learning of mathematical concepts and practical knowledge of the subject. Hence, the study adapting the TPACK conceptual framework.

\subsection{Mathematics Instruction in the University of Cape Coast}

Out of a dreadful need for highly competent and expert human resources in the education sector in Ghana, an institution namely University of Cape Coast was established in 1962 (Dwarko \& Kwarteng, 2003). Dwarko and Kwarteng (2003) further indicated that the original mandate for the establishment of the university was to prepare and train professional graduate teachers to cater for the need of the nation. Agyei (2012) indicated in his work that, an analysis of the various courses offered within the 4-year mathematics teacher education program in the university revealed two major problems which were of great relevance to this study: the state of integration of technology in preparation of teachers and the various methods of teaching used by course instructors within the mathematics education program.

Agyei (2012) further reiterated that, within the mathematics education department, the instructional course that is offered in mathematics education does not embrace the components needed to train and empower students to inculcate technology in their lessons. His assertion indicates that the mathematics education program provides a little or no opportunity for future mathematics teachers to learn about technology and ways to integrate it into their future instruction in mathematics.

\subsection{Enhancing the Application of Technology in Mathematics Education}

Krishnasamy, Veloo, and Hooi (2013) demonstrated in their work, "perceptions of teachers towards media usage in teaching mathematics in secondary school", that schools need more media facilities. The findings of Lisa (2005) indicated that sufficient media materials will increase the effectiveness in teaching mathematics and this, in turn, will reduce the workload of mathematics teachers in preparing teaching aids.

Studies by Uhomoibhi (2006) indicated that ICT usage will facilitate the delivery of mathematics lessons in the process of teaching in schools. Pramela and Noraza (2007) interviewed nine teachers from "Universiti Kebangsaan, Malaysia" concerning the practice of using ICT in teaching mathematics, his results revealed that the use of ICT has facilitated and improved the teaching and learning of mathematics. Agyei (2012) also proposed that a professional development program should be planned to train preservice teachers to inculcate technology in teaching within various teacher education programmes. Observing the vital role of technology in education, it is prudent to shift from the traditional approaches of teaching and learning mathematics to using 
technology since the former poses a serious impediment to academic achievement.

\subsection{The usefulness of Technology in the Mathematics Classroom}

Blackmore, Hardcastle, Bamblette, and Owens (2003) discovered that various teachers who utilize technology in mathematics instruction motivate students, encourage creative thinking, facilitate student understanding among others. There is, therefore, the need to train pre-service and even in-service teachers to be able to develop the ability to utilize technology by incorporating it into teacher education programs effectively. Foster (2006) indicated the benefits of computer technologies in the teaching and learning of mathematics as providing fast and accurate calculations, generation of graphs, manipulations, and solutions to equations. Thus, calculators aid in making fast and accurate calculations and also providing solutions to equations in the mathematics classroom. Application software such as Geogebra also helps in the generation of graphs and makes geometry very practical in the mathematics classroom

Finally, "Technology is essential in teaching and learning mathematics; it influences the mathematics that is taught and enhances students' learning" (National Council of Teachers of Mathematics [NCTM], 2000, p. 24). An important aspect of classroom teaching is to find ways of generating interest and satisfaction in relation to performance and learning experience. So, the process of teaching mathematics using traditional educational resources such as chalk and blackboards must be modified and varied with the use of technological educational resources such as videos, computers, audiotapes, and projectors.

\section{RESEARCH METHODS}

The study used a descriptive survey as a research design that made use of quantitative data. The study used a questionnaire that comprised a standard set of interrogations to obtain a comprehensive outline of the group's background information, thoughts, and opinions (Onley \& Barnes, 2008). The target population for the study was all Bachelor of Education (Mathematics) students at the University of Cape Coast. On the other hand, the accessible population included Level 300 and Level 400 Bachelor of Education (Mathematics) students at the University of Cape Coast. Purposive sampling was used to select Level 300 and Level 400 students for the study. In all, a total of 120 students were selected for the study. Daniel (2012) affirms that purposive sampling is more appropriate for research focused on particular segments of a target population. The study adopted purposive sampling to select these groups because they have been exposed to a greater part of the curriculum for the program. The questionnaire consisted of close-ended questions. Researchers made use of close-ended items in the questionnaire because the open-ended required a greater effort on the part of the respondent and yields little returns. Descriptive statistics (frequencies and percentages) were employed to analyze the data that was collected.

\section{RESULTS AND DISCUSSIONS}

Table 1 presents the results of the perceptions of B. Ed. Mathematics students about the inculcation of technology in mathematics education 
Table 1 - Perceptions of B. Ed. Mathematics students on ICT usage

\begin{tabular}{|l|c|c|c|c|c|}
\hline Items & $\mathrm{SD}$ & $\mathrm{D}$ & $\mathrm{U}$ & $\mathrm{A}$ & $\mathrm{SA}$ \\
\hline & $\mathrm{N}(\%)$ & $\mathrm{N}(\%)$ & $\mathrm{N}(\%)$ & $\mathrm{N}(\%)$ & $\mathrm{N}(\%)$ \\
\hline I enjoy using the computer & $4(3.3)$ & $9(7.5)$ & $9(7.5)$ & $36(30.0)$ & $62(51.7)$ \\
\hline Knowledge on a computer a worthwhile skill & $5(4.2)$ & $2(1.7)$ & $7(5.8)$ & $39(32.5)$ & $67(55.8)$ \\
\hline Enjoy lessons on the computer & $5(4.2)$ & $8(6.7)$ & $14(11.7)$ & $47(39.2)$ & $46(38.3)$ \\
\hline $\begin{array}{l}\text { Takes a long time to finish a task when using a } \\
\text { computer }\end{array}$ & $38(31.7)$ & $36(30.0)$ & $18(15.0)$ & $20(16.7)$ & $8(6.7)$ \\
\hline Focus much on the computer when I use one & $6(5.0)$ & $10(8.3)$ & $12(10.0)$ & $62(51.7)$ & $30(25.0)$ \\
\hline $\begin{array}{l}\text { Computers give me the chance to learn many new } \\
\text { things }\end{array}$ & $2(1.7)$ & $4(3.3)$ & $7(5.8)$ & $41(34.2)$ & $66(55.0)$ \\
\hline $\begin{array}{l}\text { Computers are valuable tools that can be used to } \\
\text { enhance the quality of education }\end{array}$ & $1(0.8)$ & $3(2.5)$ & $6(5.0)$ & $36(30.0)$ & $74(61.7)$ \\
\hline $\begin{array}{l}\text { I believe textbooks will be replaced by electronic } \\
\text { media }\end{array}$ & $9(7.5)$ & $8(6.7)$ & $21(17.5)$ & $44(36.7)$ & $38(31.7)$ \\
\hline $\begin{array}{l}\text { Mathematics teacher education should include } \\
\text { instructional applications of computers }\end{array}$ & $2(1.7)$ & $1(0.8)$ & $12(10.0)$ & $43(35.8)$ & $62(51.7)$ \\
\hline Computers help to integrate new teaching methods & $1(0.8)$ & $4(3.3)$ & $12(10.0)$ & $46(38.3)$ & $57(47.5)$ \\
\hline Students feel more involved in the lesson & $4(3.3)$ & $8(6.7)$ & $6(5.0)$ & $44(36.7)$ & $58(48.3)$ \\
\hline Promotes effective students' learning & $1(0.8)$ & $6(5.0)$ & $6(5.0)$ & $50(41.7)$ & $57(47.5)$ \\
\hline Learning becomes fun and more interesting & $0(0)$ & $2(1.7)$ & $13(10.8)$ & $45(37.5)$ & $60(50.0)$ \\
\hline Provision of a better learning experience & $0(0)$ & $3(2.5)$ & $9(7.5)$ & $51(42.5)$ & $57(47.5)$ \\
\hline $\begin{array}{l}\text { It makes mathematics more real and practical rather } \\
\text { than abstract }\end{array}$ & $1(0.8)$ & $2(1.7)$ & $10(8.3)$ & $50(41.7)$ & $57(47.5)$ \\
\hline
\end{tabular}

(SD: Strongly disagree, D: Disagree, U: Undecided, A: Agree, SA: Strongly agree)

From Table 1, $81.7 \%(\mathrm{n}=98)$ of the respondents agreed that they enjoy using the computer and $88.3 \%(n=106)$ of the respondents agreed that knowing how to use the computer is a worthwhile skill. Also, most of the respondents $(77.5 \%, \mathrm{n}=93)$ agreed that they enjoy lessons on the computer. More than half of the students representing $76.7 \%(\mathrm{n}=92)$ agreed to the fact that they focus much on the computer when using it. $89.2 \%(n=107)$ of the students agreed that the computer gives them the chance to learn many new things. Furthermore, the mass of the respondents showing $91.7 \% \quad(n=110)$ of the students also agreed to the statement that computers are valuable tools that can be used to enhance the quality of education. Moreover, a larger number of respondents representing $68.4 \%(n=82)$ agreed that textbooks will be replaced by electronic media. $80.8 \%(\mathrm{n}=97)$ of the students agreed to the fact that computers can help accommodate different teaching styles. A lot of the students representing $87.5 \%(n=105)$ agreed to the statement that mathematics teacher education should include instructional applications of computers. Mass of the respondents representing $85.8 \%(\mathrm{n}=103)$ agreed that computers help to integrate new teaching methods and $85 \%(n=102)$ of the respondents agreed that students feel more involved in the lesson when using the computer. Also, a greater number of the students showing $89.2 \%(\mathrm{n}=107)$ agreed that ICT integration promotes effective students' learning and $87.5 \%(\mathrm{n}=105)$ of the respondents agreed to the fact that learning becomes fun and more interesting when using ICT tools. A huge number of the students representing $90 \%(\mathrm{n}=108)$ agreed to the statement that there is a provision of a better learning experience with the aid of ICT tools and $89.2 \%$ $(n=107)$ agreed that ICT integration makes mathematics more real and practical rather than abstract. However, more than half of the respondents representing $61.7 \% \quad(n=74)$ disagreed with the statement that it takes a long time to finish a task when using a computer. It can be inferred from the findings that undergraduate mathematics education students have a positive perception of the use of technology.

It must be emphasized that these findings from the first research question which looked at the perceptions of B. Ed. (Mathematics) students about the inculcation of technology in mathematics education agrees to the findings of Pramela and Noraza (2007) who reported that the use of ICT equipment helped to gain the students' attention and maintain their interest so that they were able to acquire and master appropriate skills. They also stated that the use of ICT has facilitated and enhanced the teaching of mathematics. Lisa (2005) also stated that media materials can be used as teaching aids to help resolve the delivery of more abstract concepts. Thus, this study also conforms to the findings of Krishnasamy, Veloo, and Hooi (2013) who reported that the perceptions of mathematics teachers suggest that schools require ICT facilities to enhance the teaching and learning of mathematics.

The Table 2 below presents the responses from students on the extent B. Ed. Mathematics students of UCC are exposed to the use of technological tools in their program. 
Table 2 - Use of Technological Tools

\begin{tabular}{|l|c|c|c|c|c|}
\hline Items & NAA & AL & SW & ALT & NA \\
\hline & $\mathrm{N}(\%)$ & $\mathrm{N}(\%)$ & $\mathrm{N}(\%)$ & $\mathrm{N}(\%)$ & $\mathrm{N}(\%)$ \\
\hline Word processing packages & $15(12.5)$ & $50(41.7)$ & $25(20.8)$ & $27(22.5)$ & $3(2.5)$ \\
\hline Database software & $26(21.7)$ & $31(25.8)$ & $37(30.8)$ & $20(16.7)$ & $6(5)$ \\
\hline Spreadsheet & $13(10.8)$ & $44(36.7)$ & $35(29.2)$ & $23(19.2)$ & $5(4.2)$ \\
\hline Presentation Software & $12(10.0)$ & $41(34.2)$ & $30(25)$ & $33(27.5)$ & $4(3.3)$ \\
\hline Graphical Application & $37(30.8)$ & $38(31.7)$ & $27(22.5)$ & $9(7.5)$ & $9(7.5)$ \\
\hline Graphical Calculators & $48(40.3)$ & $28(23.3)$ & $21(17.5)$ & $10(8.3)$ & $13(10.8)$ \\
\hline Application of multimedia & $38(31.7)$ & $36(30.0)$ & $19(15.8)$ & $16(13.3)$ & $11(9.2)$ \\
\hline E-mail & $24(20.0)$ & $37(30.8)$ & $32(26.7)$ & $20(16.7)$ & $7(5.8)$ \\
\hline Internet & $13(10.8)$ & $36(30.0)$ & $30(25.0)$ & $32(26.7)$ & $9(7.5)$ \\
\hline
\end{tabular}

(NAA: Not at all, AL: A little, SW: Somewhat, ALT: A lot, NA: Not available)

From the table above, most of the respondents representing $41.7 \%(n=50)$ indicated that they are a little exposed to the application of word processing packages. The majority of the respondents representing $30.8 \%(n=37)$ claimed that they are somewhat exposed to the application of database software. Moreover, a greater part of the students representing $36.7 \%(\mathrm{n}=44)$ asserted that they are a little exposed to the application of spreadsheets. A larger part of the respondents representing 34.2\% $(n=41)$ indicated that they are a little exposed to the application of presentation software. Also, the majority of the respondents representing $31.7 \%(n=38)$ declared that they are a little exposed to graphical applications in their learning. $40.3 \%(n=48)$ of the students claimed that they are not exposed to the application of graphical calculators. $31.7 \%(\mathrm{n}=38)$ of the respondents indicated that they are not exposed to the application of multimedia. Furthermore, most of the respondents representing 30.8\% ( $n=37)$ asserted that they are a little exposed to the use of e-mails. Lastly, a bulk of the respondents representing $30.0 \%(n=36)$ indicated that they are a little exposed to the use of the internet in learning.

The findings revealed that several technological tools such as word processing packages, spreadsheets, database software, graphical calculators, application of multimedia among others are hardly used by students in mathematics instruction at the mathematics education department. The findings of the study also showed that, the extent to which B. Ed. Mathematics students in the university are exposed to the application of technology in their learning as a means of preparing them to incorporate ICT into their teaching in the second cycle of education is very low. The findings conform to the study of Agyei (2012) where it was reported that, within the mathematics education department, the instructional course that is offered in mathematics education does not embrace the components needed to train and empower students to inculcate technology in their lessons. Also, the findings conform to the research of Hardy (2003) who discovered that research done in Canada exposed both in-service and pre-service mathematics teachers perceive that they are not trained and prepared adequately and are often not given suitable instruments to incorporate technology in their classrooms.

\section{CONCLUSIONS}

The key findings of this study revealed that mathematics education students have a positive perception of the usage of technology in teaching and learning of mathematics. With regards to the extent to which B. Ed. Mathematics students of UCC are exposed to the use of technological tools in their program, the researchers found out that students are not exposed to the application of graphical calculators and multimedia. Students are somewhat exposed to the application of database software. Also, respondents indicated that they are a little exposed to the application of the following: word processing packages, spreadsheets, presentation software, graphical software, e-mail, and the internet. It can be concluded that Bachelor of Education (Mathematics) students of the University of Cape Coast are not fully exposed to the use of technology in their mathematics instruction.

\section{IMPLICATIONS}

Considering the research findings and conclusions, it is recommended that further development and use of educational technology for both students and teachers should be given the maximum attention as a useful investment for educational success. Also, Educational Administrators must pay attention to integrating ICT in mathematics education. Hence, programs offered in teacher education and professional development must consistently assist learners in their development of knowledge about technology and its usage to promote teaching and learning of mathematics.

\section{LIMITATIONS}

The study was restricted to the University of Cape Coast. This may have an adverse consequence on the generalization to be made for all the various Universities in Ghana. Also, the researchers were unable to gather all the needed information from the population due to the use of a questionnaire as the tool for data collection.

\section{REFERENCES}

[1] Addy, N. A. \& Ofori-Boateng, P. (2015). ICT and Education: An analysis of Ghana's Universities. International Journal of ICT and Management, 3(2), 23-28.

[2] Agyei, D. D. (2012). Preparation of Pre-Service Teachers in Ghana to Integrate Information Communication and Technology in Teaching Mathematics. Twente: Ipskamp Drukkers B. V. Enschede.

[3] Blackmore, J., Hardcastle, L., Bamblett, E., \& Owens, J. (2003). Effective use of information and communication technology (ICT) to enhance learning for disadvantaged school students. Deakin Centre for Education and Change, Institute of Disability Studies, Deakin University and Institute of Koorie Education, Deakin University, Australia.

[4] Cox, S. \& Graham, C. R. (2009). Using an elaborated model of the TPACK framework to analyze and depict teacher knowledge. TechTrends, 53(5), 6069. 
[5] Daniel. J. (2012). Choosing the tvpe of nonprobabilitv samnling. In Daniel. J. Samnling essentials: Practical guidelines for making samnling choices (pp. 81-124). Thousand Oaks, CA: SAGE Publications.

[6] Dwarko D. A. and Kwarteng O. K. (2003). A History of University of Cape Coast: Forty years of resilience (1962-2002). Accra: Worli Publishing services.

[7] Foster, J. (2006). Collaborative information seeking and retrieval. Annual review of information science and technology, 40(1), 329-356.

[8] Hardy, (2003). Personality indicators and emergency permit teachers' willingness to embrace technology. Journal of Instructional Psychology. 30 (3), 185.

[9] Intsiful, J., Okyere, P. F. \& Osae, S. (2003). Use of ICT for Education, Research and Development in Ghana: Challenges, Opportunities, and Potentials Round Table on Developing Countries Access to Scientific Knowledge. Trieste, Italy: The Abdus Salam ICTP.

[10] Karehka, R. (2012). Modern Technology Advantages and Disadvantages. Use of Technology, 6.

[11] Krishnasamy, H. N., Veloo, A., \& Hooi, N. S. (2013). Perception of Teachers towards Media Usage in Teaching Mathematics in Secondary Schools. Procedia-Social and Behavioral Sciences, 112, 1093-1098.

[12] Lisa (2005). E-Pembelajaran Interaktif - Penyelesaian Pengajaran Dan Pembelajaran. Diperolehi Ogos 13, 2008.

[13] Lowerison, G., Sclater, J., Schmidt, R. F., \& Abrami, P. C. (2012). Student Perceived effectiveness of computer technology use in post-secondary classrooms. Computers \& education. 47, 465-489.

[14] Mishra, P., \& Koehler, M. J. (2006). Technological pedagogical content knowledge: A framework for teacher knowledge. Teachers college record, 108(6), 1017.

[15] National Council of Teachers of Mathematics (Ed.). (2000). Principles and standards for school mathematics (Vol. 1). National Council of Teachers of Mathematics. p. 24.

[16] Niess, M. L. (2011). Investigating TPACK: Knowledge growth in teaching with technology. Journal of educational computing research, 44(3), 299317.

[17] Odedra, M., Lawrie, M., Bennett, M. \& Goodman, S. (2008). Information Technology in Sub-Saharan Africa. Retrieved from University of Pennsylvania - African Studies Center: http://www.africa.upenn.edu/
[18] Onley, A. C., \& Barnes, S. (2008). Collecting and Analysing Evaluation Data. Plan and Evaluating Health Information Outreach Projects, Booklet, 3

[19] Pramela, K., \& Noraza, A. Z. (2007). Teachers and the new ICT challenges Jurnal e-Bangi, 2(2), 1-13.

[20] Roblyer, M. (2013). Integrating Educational Technology into Teaching. Upper Saddle River, NJ: Merrill Prentice Hall.

[21] Strauss, M. (2017, October 12). Four-in-ten Americans credit technology with improving life most in the past 50 years. Retrieved from Pew Research Center: http://www.pewresearch.org/fact-tank/2017/10/12/four-in-tenamericans-credit-technology-with-improving-life-most-in-the-past-50years/

[22] Thompson, A. D., \& Mishra, P. (2007). Editors' Remarks: Breaking News: TPCK Becomes TPACK! Journal of Computing in Teacher Education, 24(2), 38-64.

[23] Uhomoibhi, J. O. (2006). Implementing e-learning in Northern Ireland: prospects and challenges. Journal of Campus-Wide Information Systems, 23(1) 4-14.

[24] Voogt, J., Fisser, P., Pareja Roblin, N., Tondeur, J., \& van Braak, J. (2013). Technological pedagogical content knowledge-a review of the literature. Journal of computer-assisted learning, 29(2), 109-121.

\section{AUTHORS}

First Author - Emmanuel, Agyei, Mphil student, Department of Mathematics and ICT Education, University of Cape Coast, Ghana, emmanuel.agyei@stu.ucc.edu.gh.

Second Author - Bernard Wiafe Akaadom, PhD, Department of Mathematics and ICT Education, University of Cape Coast, Ghana, bernard.akaadom@ucc.edu.gh.

Third Author - Bright Kwaku Manu, Mathematics teacher, Ghana Christian International School, manubright48@gmail.com.

Correspondence Author - Emmanuel, Agyei, emmanuel.agyei@stu.ucc.edu.gh, agyeiemma1995@gmail.com, +233543096189 . 